\title{
OBITUARY
}

\section{Professor Réné Basset}

By the death of Réné Basset the world of learning has lost an eminent scholar, whose publications, especially in connexion with North Africa, are much valued. Born at Lunéville in 1855, he began his career as a teacher in the École Supérieure des Lettres of Algiers at the age of 25 and rose to become Director of this institution; indeed, Algiers was the scene of his activities throughout the whole of his career, and he was Dean of the Faculty of Letters in the University there at the time of his death, 4th January, 1924. His literary activity was abundant and embraced many interests; he published and translated several Arabic texts on the history of Ethiopia, the geography of North Africa, and a number of poems ; to the language of the Berbers he devoted especial attention and gave a considerable impulse to the scientific study of the various Berber dialects. He took a special interest in folklore and collected a large number of Berber and other stories in northern Africa. From the outset he was the editor of the French edition of the Encyclopaedia of Islam, to which he himself contributed a large number of articles. A frequent contributor to learned journals, such as the Journal Asiatique, La Revue Africaine, etc., his articles always provided some fresh scientific materials, and will be missed by all students of the language and culture of North Africa. 